Article

\title{
Investigating Useful Properties of Four Streptomyces Strains Active against Fusarium graminearum Growth and Deoxynivalenol Production on Wheat Grains by qPCR
}

\author{
Elena Maria Colombo ${ }^{\dagger}$, Andrea Kunova ${ }^{*}+\oplus$, Claudio Gardana $₫$, Cristina Pizzatti, \\ Paolo Simonetti ${ }^{D}$, Paolo Cortesi, Marco Saracchi ${ }^{(D)}$ and Matias Pasquali ${ }^{(D)}$ \\ Department of Food, Environmental and Nutritional Science (DeFENS), University of Milan, 20133 Milan, Italy; \\ elenamaria.colombo@unimi.it (E.M.C.); claudio.gardana@unimi.it (C.G.); cristina.pizzatti@unimi.it (C.P.); \\ paolo.simonetti@unimi.it (P.S.); paolo.cortesi@unimi.it (P.C.); marco.saracchi@unimi.it (M.S.); \\ matias.pasquali@unimi.it (M.P.) \\ * Correspondence: andrea.kunova@unimi.it \\ t These authors contributed equally.
}

Received: 8 July 2020; Accepted: 26 August 2020; Published: 31 August 2020

\begin{abstract}
Streptomyces spp. can be exploited as biocontrol agents (BCAs) against plant pathogens such as Fusarium graminearum, the main causal agent of Fusarium head blight (FHB) and against the contamination of grains with deoxynivalenol (DON). In the present research, four Streptomyces strains active against $F$. graminearum in dual plate assays were characterized for their ability to colonize detached wheat grains in the presence of $F$. graminearum and to limit DON production. The pathogen and BCA abundance were assessed by a quantitative real-time PCR, while DON production was assessed by HPLC quantification and compared to ergosterol to correlate the toxin production to the amount of fungal mycelium. Fungal growth and mycotoxin production were assessed with both co-inoculation and late inoculation of the BCAs in vitro (three days post-Fusarium inoculation) to test the interaction between the fungus and the bacteria. The level of inhibition of the pathogen and the toxin production were strain-specific. Overall, a higher level of DON inhibition (up to 99\%) and a strong reduction in fungal biomass (up to $71 \%$ ) were achieved when streptomycetes were co-inoculated with the fungus. This research enabled studying the antifungal efficacy of the four Streptomyces strains and monitoring their development in DON-inducing conditions.
\end{abstract}

Keywords: biocontrol; mycotoxin; Triticum aestivum; qPCR; ergosterol

Key Contribution: The paper develops a qPCR assay to study Streptomyces and F. graminearum amount in wheat grains and uses the method to assess how four different active BCAs grow in the presence of F. graminearum. Moreover, it shows that Streptomyces growth and antifungal and antimycotoxigenic activities are unique to each strain.

\section{Introduction}

Fusarium head blight (FHB) is one of the most devastating cereal diseases, especially for wheat and barley. It is caused by a complex group of Fusarium spp., in which Fusarium graminearum is the main causal agent $[1,2]$. Severe yield losses occur in the field, together with a variable level of grain contamination with mycotoxins belonging to the group of type B trichothecenes, such as deoxynivalenol (DON) [3]. The fungal contamination in harvested grains can be kept under control during the storage period, but the mycotoxin incidence in feed and food products often increases 
dramatically, becoming a threat for food and feed safety [4,5]. The risks to human and animal health have forced organizations worldwide to establish standards for maximum allowable levels in products for human consumption [6]. The toxic effects of DON include the alteration of intestinal, nervous, and immune systems due to the inhibition of protein synthesis and induction of apoptosis [7].

Several control strategies to manage FHB incidence and consequent DON contamination in harvested grains have been exploited in the field, such as the development of resistant varieties, application of fungicides, and crop rotation [8]. Nevertheless, some agricultural practices can promote Fusarium development or enhance mycotoxin accumulation under favorable environmental conditions [9]. As integrative approaches to manage FHB are urgently needed, research on biocontrol agents (BCA) has been receiving increased attention [10]. Biological control is an environmentally friendly approach to fight plant pathogens using microbial antagonists. The complex epidemiology of FHB enables applying antagonists to seeds, crop residues, or to the spikes [11], as well as during post-harvest [12].

Streptomyces spp. are Gram-positive bacteria belonging to the phylum Actinobacteria, ubiquitous in soil, and commonly exploited for antibiotic production in human and veterinary medicine. They grow through a combination of tip extension and branching of hyphae, forming a vegetative mycelium. Later, in response to nutrient depletion and other signals, they form aerial mycelium-carrying spores $[13,14]$. In correspondence with these morphological changes, they produce a variety of secondary metabolites active against possible competitors present in their niche [15]. Recently, Streptomyces have also been found to establish symbiotic interactions with plants and other eukaryotes [16]. Therefore, they have the potential to become key players for developing novel strategies against plant pathogens and to limit toxin contamination thanks to the discovery of promising metabolites for crop protection [17]. Indeed, recent studies confirmed their ability to reduce toxigenic Fusarium spp. growth and disease severity in controlled and field conditions [18-20], as well as DON production in vitro and in planta [21-23]. Currently, only two commercial products based on live Streptomyces spp. are available on the European market (Mycostop ${ }^{\circledR}$ and Actinovate ${ }^{\circledR}$ ) and neither of them were specifically registered for FHB management [24], despite showing certain activity against F. graminearum [25]. However, diverse Streptomyces strains are likely to become part of the tools available for integrated disease control in the near future as shown by some recent patent depositions [26].

In an effort to select novel Streptomyces strains able to counteract fungal and mycotoxin contamination in a wheat-Fusarium pathosystem, their survival on wheat grains and the potential inhibitory effect of a co-culture with the pathogen needs to be assessed. Indeed, biological interactions between Streptomyces and Fusarium are crucial to understand how possible disease control can be employed and exploited [27].

Ergosterol quantification is routinely used to determine the microbiological status of grains and feeds [28-30] and can be exploited to evaluate the effect of a fungicide or a natural product on fungal pathogen growth [31,32]. This fungal marker can also be used to normalize mycotoxin levels based on fungal development [33,34]. Moreover, in recent years, quantitative real-time PCR (qPCR) has been recognized as a rapid and highly sensitive technique to accurately quantify fungal and bacterial biomass in a wide range of food and grain samples [35], a parameter which can be easily correlated with the level of disease observed in the field as well as mycotoxin contamination [36,37]. Additionally, as qPCR is able to detect specific strains, it has been increasingly used for BCA monitoring in the target substrate [38], enabling the assessment of BCA survival under specific abiotic and biotic conditions, as well as the influence of time and application method on its survival [39].

In order to study the mechanism of action of four promising Streptomyces strains [40,41] against F. graminearum growth and toxin production (DON) in vitro, specific qPCR methods were developed to monitor both fungal and BCA strains. These analyses were combined with ergosterol quantification to support the qPCR-based quantification and to normalize the DON content in flour samples.

The goals of the paper were to test whether in DON-inducing conditions (1) fungal growth is affected by the tested Streptomyces strains; (2) toxin production is affected by the tested Streptomyces 
strains; (3) Streptomyces strain development is affected by pathogen presence; and (4) the timing of Streptomyces inoculation determines their efficacy as BCA in in vitro conditions.

\section{Results}

\subsection{Streptomyces Influence on Fungal Growth}

Four Streptomyces strains (DEF09, DEF20, DEF39, and DEF48) were selected on the basis of their promising biocontrol activity against $F$. graminearum $[40,41]$. The effect of the Streptomyces strains on fungal growth on wheat grains was evaluated at two different inoculation times $(0$ or 3 days post-pathogen inoculation; DPI). Fusarium graminearum was quantified by HPLC ergosterol determination and a qPCR based on the TRI12 gene. Only traces or no detectable levels of ergosterol or qPCR amplifications were detected in blank samples (no-BCA or fungal treatment), confirming that the used seeds were free of F. graminearum (Table S1). In addition, the ratios of the fungal amount in the control to that in the treated samples were calculated for both the ergosterol and the qPCR method in order to assess the correlation between the two quantification methods. A correlation value of 0.82 was obtained (Figure S1).

When DEF09, DEF20, DEF39, and DEF48 strains were co-cultured with F. graminearum from the first day of inoculation (0 DPI), the fungal growth was clearly inhibited by all Streptomyces spp. strains $(p<0.05)$ (Figures 1A,B; 2A,B and S2). Instead, the inoculations of DEF09, DEF20, DEF39, and DEF48 strains at three days after fungal inoculation (3 DPI) were conducted to simulate a treatment of an already established Fusarium infection, and did not result in any antifungal effect as measured by ergosterol amounts or fungal abundance (Figures 1C,D; 2C,D and S2). All $p$-values from the ANOVA analyses are listed in Table S2.
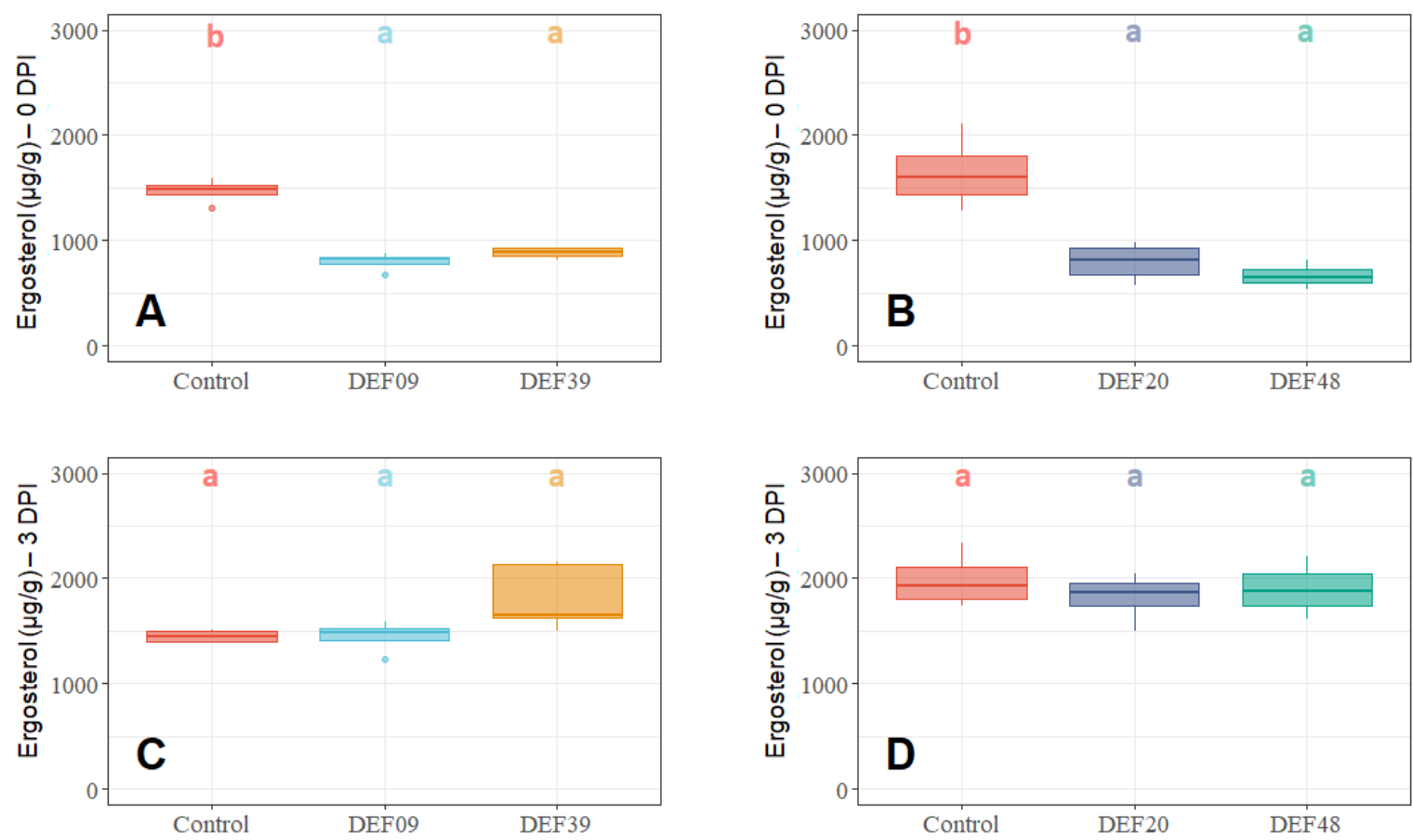

Figure 1. Ergosterol quantification $(\mu \mathrm{g} / \mathrm{g})$ in wheat grain samples treated with Streptomyces spp. DEF09, DEF39, DEF20, and DEF48 at 0 days post-inoculation (0 DPI) $(\mathbf{A}, \mathbf{B})$ and 3 DPI $(\mathbf{C}, \mathbf{D})$ after 11 days of incubation. The presence of different control replicates (no-biocontrol agent (BCA) treatment) is due to multiple experiments being performed. Means of four replicates in two technical repetitions were subjected to ANOVA and a post hoc Tukey's HSD test. Box-plots with the same letters on top of the graph are not significantly different according to Tukey's HSD test $(p<0.05)$. 

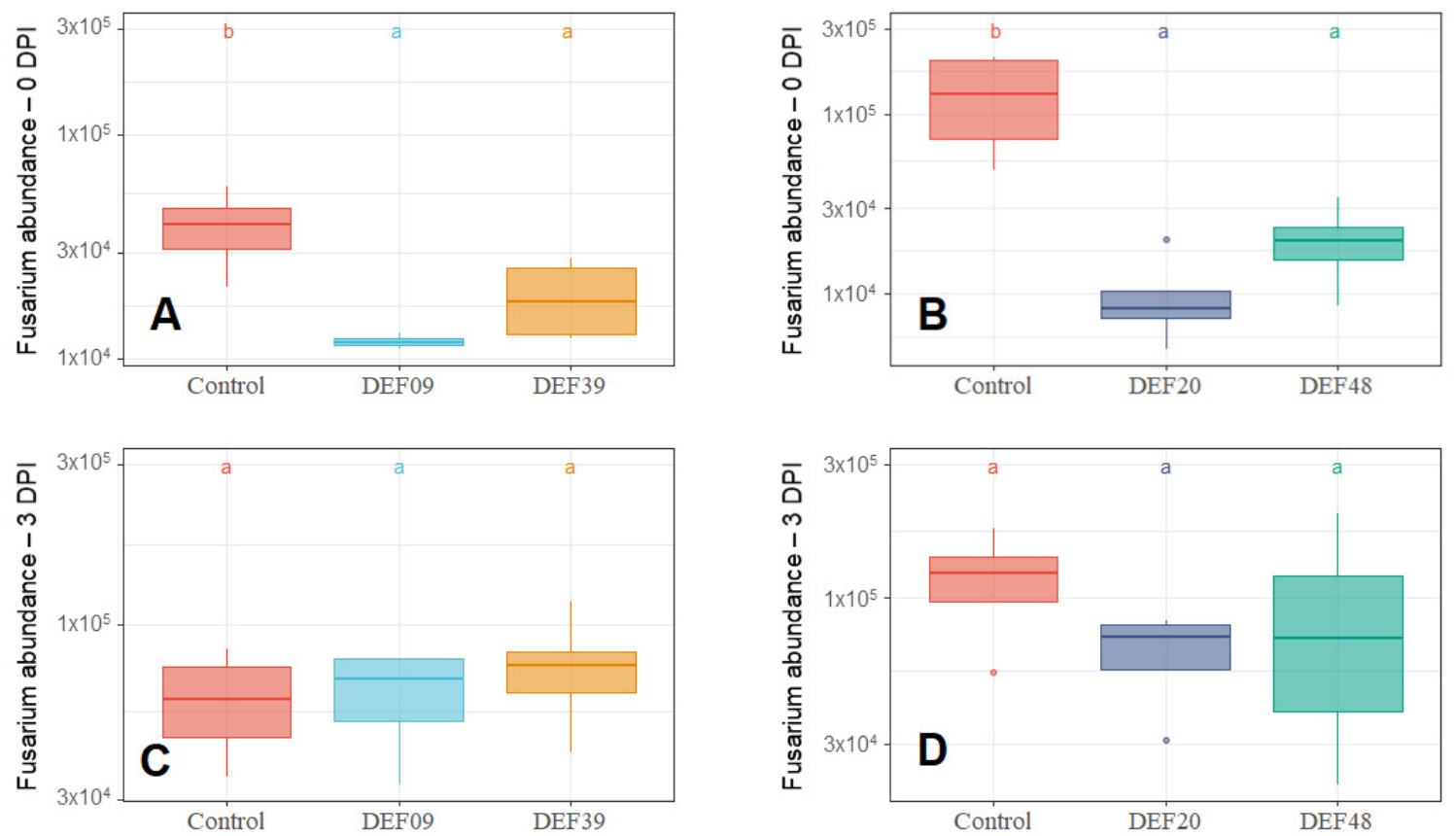

Figure 2. Fusarium graminearum CS3005 abundance normalized to wheat abundance in wheat grain samples treated with Streptomyces spp. DEF09, DEF39, DEF20, and DEF48 at 0 DPI (A,B) and 3 DPI (C,D) after 11 days of incubation. The presence of different control replicates (no-BCA treatment) is due to multiple experiments being performed. Abundance was calculated as a ratio of Fusarium DNA to wheat DNA quantity. The means of four replicates were subjected to ANOVA and a post hoc Tukey's HSD test. Box-plots with the same letters on top of the graph are not significantly different according to Tukey's HSD test $(p<0.05)$.

The BCAs were able to limit the ergosterol content (Fusarium growth) up to $45 \%, 52 \%, 40 \%$, and $60 \%$ for DEF09, DEF20, DEF39, and DEF48, respectively. Fusarium abundance was reduced up to $70 \%, 92 \%, 50 \%$, and $85 \%$ for DEF09, DEF20, DEF39, and DEF48, respectively. The highest Fusarium inhibition was recorded for DEF20 and DEF48 treatments, suggesting they were the most effective strains in limiting Fusarium growth, and this conclusion was consistent for both the qPCR and the ergosterol analyses.

\subsection{Fitness of the Streptomyces Strains on Wheat Grains}

To assess the fitness of the four Streptomyces spp. strains used in this study, their abundance was evaluated both on control- and Fusarium-contaminated wheat grains using a qPCR analysis targeting the Streptymyces recA gene region. Although the abundance of the four Streptomyces spp. was variable on control wheat seeds (Figure $3 \mathrm{~A}$ ), these differences were not statistically significant. Instead, the development of the majority of Streptomyces strains was clearly influenced by the presence of the pathogen on Fusarium-contaminated wheat grains (Figure 3B). The $t$-test comparison highlighted the differences among BCA development in co-culture with CS3005 or when cultured alone. In particular, DEF48 showed significantly increased growth $(p=0.03)$, while DEF09 and DEF39 were clearly inhibited by the presence of the fungus ( $p=0.03$ and $p=0.00$ ). Despite their reduced growth, they were still able to exert antifungal activity against the pathogen (Figures 1A and 2A). DEF20 was not influenced by the co-culture with F. graminearum CS3005 ( $p=0.87$ ). Overall, DEF20 and DEF48 demonstrated a great ability to colonize the substrate and to exhibit a strong antifungal effect in the tested conditions. 


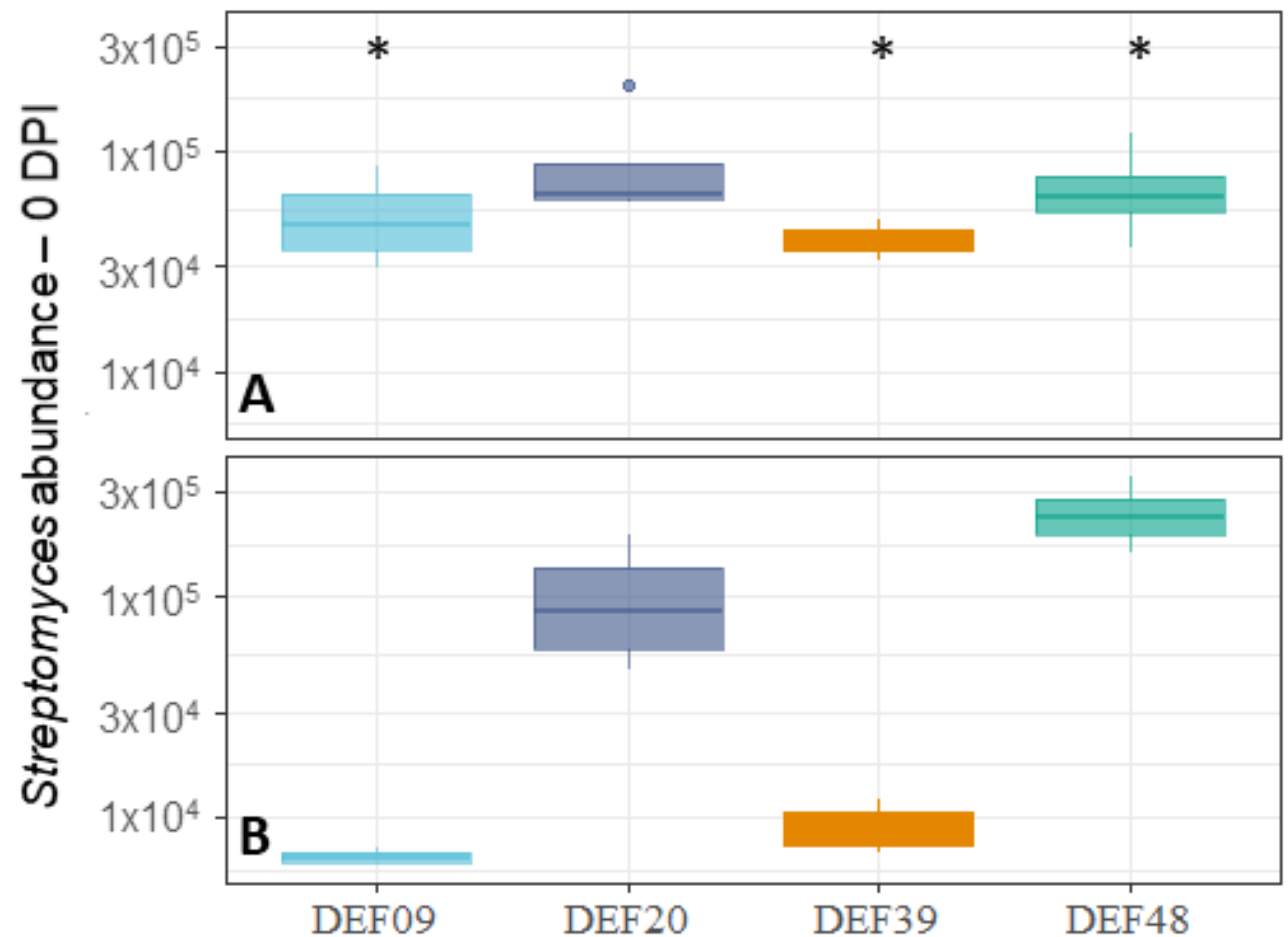

Figure 3. Streptomyces spp. strain abundance normalized to wheat abundance in wheat grain samples after 11 days of incubation. ${ }^{*} p<0.05$ was considered significant in the $t$-test comparison between control replicates (Streptomyces alone; (A)) and 0 DPI treatment (Streptomyces strain + F. graminearum CS3005; (B)) abundance was calculated as a ratio of Streptomyces DNA to wheat DNA quantity.

\subsection{Influence of the BCA Treatment on Mycotoxin Production on Detached Wheat Grains}

To verify the ability of the biocontrol Streptomyces spp. strains to limit toxin production, DON amounts were expressed as $\mu \mathrm{g} / \mathrm{mg}$ of ergosterol to normalize mycotoxin production to fungal growth [42]. Similarly to what was observed for fungal quantification (Figures 1 and 2), when co-cultured (0 DPI), all four BCAs significantly reduced mycotoxin production (Figure 4A,B). Instead, no significant decrease in toxin amount was recorded when streptomycetes were applied three days after pathogen inoculation (3 DPI, Figure 4C,D).

All strains were able to effectively reduce DON production $(\mu \mathrm{g} / \mathrm{mg}$ ergosterol) at 0 DPI treatment according to the following percentages: $71 \%, 94 \%, 83 \%$, and $99 \%$ for DEF09, DEF20, DEF39, and DEF48, respectively. 

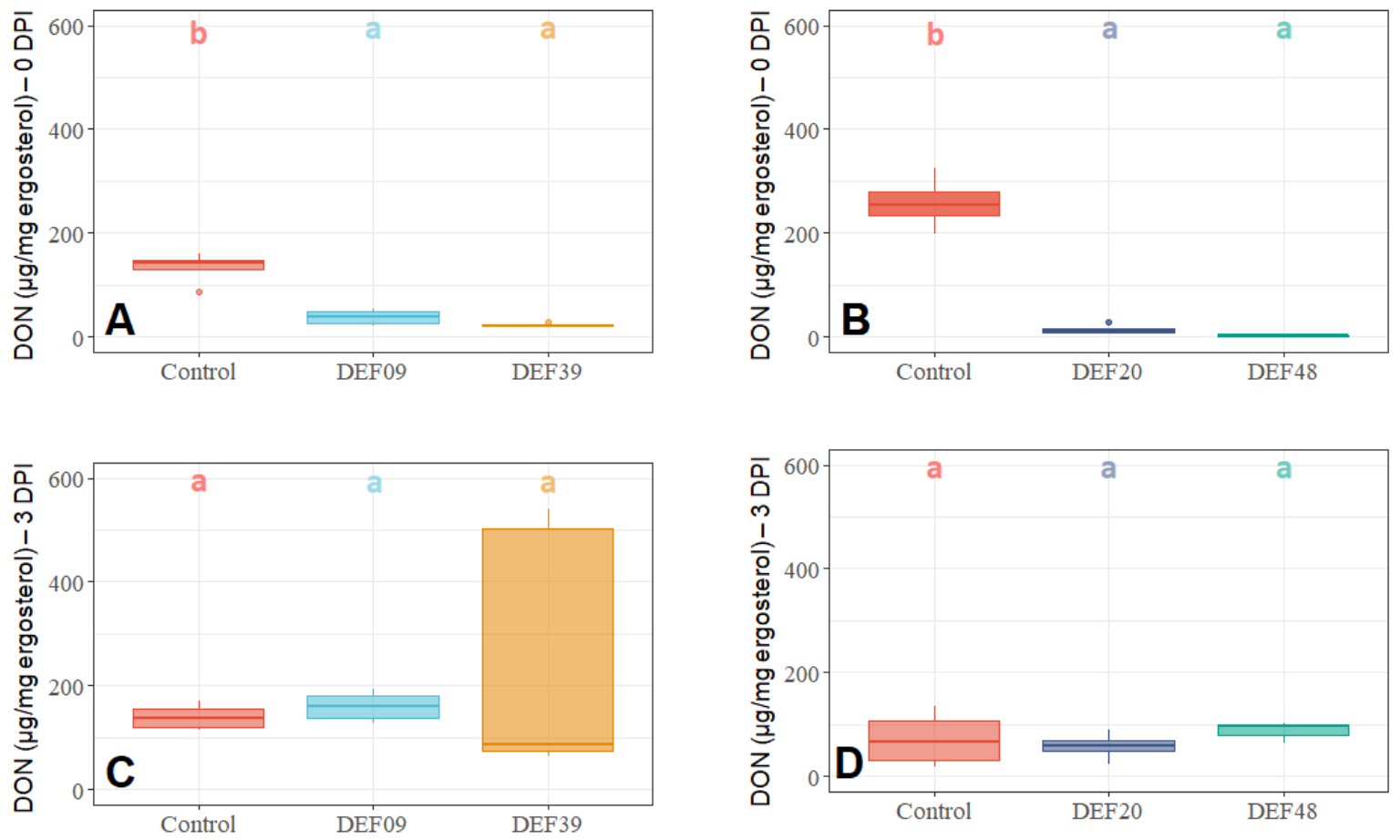

Figure 4. Deoxynivalenol (DON) quantification $(\mu \mathrm{g} / \mathrm{mg}$ ergosterol) in wheat grain samples treated with Streptomyces spp. DEF09, DEF39, DEF20, and DEF48 at 0 DPI (A,B) and 3 DPI (C,D) treatment after 11 days of incubation. The presence of different control replicates (no-BCA treatment) is due to multiple experiments being performed. Means of four replicates were subjected to ANOVA and a post hoc Tukey's HSD test. Box-plots with the same letters on top of the graph are not significantly different according to Tukey's HSD test $(p<0.05)$.

\section{Discussion}

Our study contributes to deciphering the interactions occurring between Streptomyces strains and a toxigenic strain of $F$. graminearum in a controlled environment, attempting a first characterization of four promising Streptomyces strains to be used as BCAs (Table 1). Direct antifungal activity was observed only when the bacteria and the fungus were co-inoculated (0 DPI treatment), confirming that early streptomycete inoculation is a prerequisite for their use as BCAs. These results have important implications on the development of BCAs effective in controlling mycotoxin accumulation in grains. 
Table 1. Strain ID, isolation source of the endophytic strains, in vitro inhibition of $F$. graminearum growth in dual plate assays, protection against Fusarium foot rot (FFR) symptoms on wheat plants in greenhouses, effect on F. graminearum growth on wheat grains, inhibition of DON production, and possible mechanism of reduction of toxin accumulation by different strains. The underlined data are previously published results [40,41].

\begin{tabular}{|c|c|c|c|c|c|c|c|c|}
\hline \multirow[t]{2}{*}{ Strain } & \multirow[t]{2}{*}{$\begin{array}{l}\text { Isolation } \\
\text { Source }\end{array}$} & \multirow{2}{*}{$\begin{array}{c}\text { Fungal Growth } \\
\text { Inhibition in vitro } \\
{[40,41]}\end{array}$} & \multirow{2}{*}{$\begin{array}{c}\text { FFR Reduction on } \\
\text { Plants (Greenhouse) } \\
{[40,41]}\end{array}$} & \multicolumn{2}{|c|}{$\begin{array}{c}\text { Inhibition of } F \text {. graminearum } \\
\text { Mycelium Growth on Grains } \\
\text { at 0DPI }\end{array}$} & \multirow{2}{*}{$\begin{array}{l}\text { Toxin Inhibition in } \\
\text { Grains Infected by } F \text {. } \\
\text { graminearum } 0 \text { DPI }\end{array}$} & \multirow{2}{*}{$\begin{array}{l}\text { Streptomyces Growth } \\
\text { in Grains Infected by } \\
\text { F. graminearum } 0 \text { DPI }\end{array}$} & \multirow{2}{*}{$\begin{array}{c}\text { Possible } \\
\text { Mechanism of } \\
\text { DON Reduction }\end{array}$} \\
\hline & & & & qPCR & Ergosterol & & & \\
\hline DEF09 & $\begin{array}{l}\text { Triticum } \\
\text { aestivum }\end{array}$ & $\underline{59 \%}$ & $\underline{46 \%}$ & $70 \%$ & $45 \%$ & $71 \%$ & - & $\begin{array}{l}\text { Mostly mycelium } \\
\text { growth reduction }\end{array}$ \\
\hline DEF20 & Carex sp. & $\underline{78 \%}$ & $\underline{11 \%}$ & $92 \%$ & $52 \%$ & $94 \%$ & $=$ & $\begin{array}{l}\text { Mostly mycelium } \\
\text { growth reduction }\end{array}$ \\
\hline DEF39 & Secale cereale & $\underline{64 \%}$ & $\underline{0 \%}$ & $50 \%$ & $40 \%$ & $83 \%$ & - & $\begin{array}{c}\text { Specific toxin } \\
\text { inhibition } \\
\text { independent from } \\
\text { inhibition of } \\
\text { mycelium growth }\end{array}$ \\
\hline EF48 & Zea mays & $\underline{70 \%}$ & $\underline{29 \%}$ & $85 \%$ & $60 \%$ & $99 \%$ & + & $\begin{array}{l}\text { Mostly mycelium } \\
\text { growth reduction }\end{array}$ \\
\hline
\end{tabular}

Table footer: "-" reduced growth compared to control, "=" equal growth compared to control, "+" increased growth compared to control. 
The fact that the antimycotoxigenic activity is most probably a consequence of the antifungal activity suggests that the BCA needs to colonize the seed before the fungus becomes established, and no curative effects can be expected as confirmed by the absence of the inhibition of fungal growth and mycotoxin production following the treatment at 3 DPI. This might be linked to the Streptomyces developmental program, which requires colonization of the substrate with the formation of a vegetative mycelium, and the aerial mycelium with spore production and the synthesis of bioactive compounds occur only in response to nutrient depletion and other signals [14]. Our results are in accordance with previous observations where a higher mycotoxin reduction was obtained after treating peanut grains with a Streptomyces strain in a preventive way ( $24 \mathrm{~h}$ before pathogen inoculation) [43]. The appropriate strategy of streptomycete application can substantially improve their efficacy under complex environmental conditions; indeed, several reports have highlighted the importance of allowing the Streptomyces spp. to get pre-established in the host tissue/substrate [24,44].

The four studied strains showed different development at 0 DPI. Although DEF09 and DEF39 showed reduced growth in the presence of Fusarium in comparison with the control without fungal inoculation, they were still able to reduce mycotoxin production and fungal growth. DEF20 growth was not affected by co-inoculation with the pathogen. Surprisingly, DEF48 biomass increased in response to co-culture with CS3005, and moreover, it showed the highest inhibition of ergosterol and mycotoxin levels, confirming previous reports on the variety of interactions between fusaria and Streptomyces [20]. Indeed, some strains can also benefit from the production of fungal metabolites $[45,46]$ and, during this interaction, the production of antifungal metabolites can be elicited [47-49]. Therefore, further studies are needed on the interaction with multiple fungi causing DON accumulation [50] to decipher the specific mechanism of activity and the reliability of the BCA in the environment.

A key aspect in the selection of BCAs against toxigenic Fusarium spp. is the evaluation of their ability to counteract mycotoxin production [51]. Indeed, the reduction in pathogen development does not always correspond to a reduction in toxin level [52,53]. In the present research, treated samples at 0 DPI not only had inhibited Fusarium growth but also reduced mycotoxin levels in comparison to control treatments. A strong level of DON inhibition ( $\mu \mathrm{g} / \mathrm{mg}$ ergosterol) of above $94 \%$ was recorded for DEF20 and DEF48 in parallel with a strong reduction in fungal biomass. High chitinase activity was described for these two strains in a previous study [41], but we cannot exclude contemporary production of other bioactive metabolites able to suppress pathogen development, a common trait characterizing the Streptomyces genus [54]. Interestingly, DEF39 showed a remarkable decrease in toxin production ( $83 \%$ ) and the lowest inhibition of fungal biomass (40\% of ergosterol inhibition). Chitinase activity was weak for this strain [41], suggesting that within its arsenal of secondary metabolites it also harbors the potential to regulate toxin production via specific mechanisms that are not linked to antibiosis alone. Several microbial metabolites have been characterized for their specific inhibitory activity against aflatoxins produced by Aspergillus parasiticus, such as dioctatin A, blasticidin A, and aflastatin A [55-57]. Future studies will characterize the metabolites of the strain DEF39 to decipher their bioactivity.

In our study, we characterize the behavior of four promising novel BCAs against toxigenic $F$. graminearum, analyzing their ability to inhibit both fungal growth and DON production on wheat grains. As reported in Table 1, our results identify peculiar characteristics of the four analyzed strains: DEF48 has the highest capacity to inhibit fungal growth, DEF20 growth is not influenced by fungal presence, and DEF39 is able to limit DON production in an effective manner despite the low fungal growth inhibition. The panel included also DEF09 that showed very effective inhibition of fungal growth and disease establishment when interacting with the plant in field conditions [41]. In the present study, the DEF09 strain showed lower but significant inhibition of fungal growth and toxin production, confirming that mechanisms of fungal growth inhibition are active in this strain also on detached grains. Our study identifies peculiarities of each strain that can be exploited for generating complex consortia able to effectively limit the disease [58,59]. Hopefully, future integration of omics analyses of the biocontrol strains may lead to the identification of effective molecules able to block 
fungal growth and modulate toxin biosynthesis [60] as well as to the understanding of mechanisms that modulate growth by sensing the fungal neighbor. A promising approach to developing novel targeted strategies to limit the damage of toxin accumulation in food and feed can come from the integration of this knowledge [61].

\section{Materials and Methods}

\subsection{Microorganisms}

The four Streptomyces strains (DEF09, DEF20, DEF39, and DEF48) used in this work were part of a collection of isolates maintained in the laboratory of Plant Pathology at the Department of Food, Environmental and Nutritional Sciences (DeFENS), University of Milan, Italy. They were originally isolated from the inner root tissues of graminaceous plants [62]: DEF09 from wheat, DEF20 from Carex sp., DEF39 from rye, and DEF48 from corn [40]. These strains showed promising biocontrol features in vitro and in planta against $F$. graminearum in previous works, being able to limit the growth of various Fusarium strains in dual culture by over 40\% [40,41]. They were grown on Czapek yeast extract medium (CZY: 35 g/L Czapek dox broth, Difco Laboratories, Detroit, MI, USA; 2 g/L yeast extract, Difco Laboratories, Detroit, MI, USA; $15 \mathrm{~g} / \mathrm{L}$ agar; Amresco Inc., Solon, $\mathrm{OH}, \mathrm{USA})$ for 14 days at $24{ }^{\circ} \mathrm{C}$. Spores were collected by adding $5 \mathrm{~mL}$ of $10 \%$ sterile glycerol (ICN Biomedicals, Irvine, CA, USA) + $0.01 \%$ Tween 20 solution (Sigma-Aldrich, St. Louis, MO, USA) to the plate and scraping the surface of the colonies with a sterile loop. The concentration was determined using a haemocytometer and adjusted to $2 \times 10^{7}$ spores $/ \mathrm{mL}$. Small aliquots were then stored at $-20^{\circ} \mathrm{C}$.

The toxigenic Fusarium strain used in this study was F. graminearum CS3005 [63]. The strain was grown on V8 medium (200 mL/L V8 juice, Campbell Soup Company, Camden, NJ, USA; $2 \mathrm{~g} / \mathrm{L} \mathrm{CaCO}$, Sigma-Aldrich, St. Louis, MO, USA; $15 \mathrm{~g} / \mathrm{L}$ Agar, Amresco Inc., Solon, $\mathrm{OH}, \mathrm{USA}$ ) for five days at $24{ }^{\circ} \mathrm{C}$.

\subsection{BCA treatments on Wheat Grains}

Wheat grains of Triticum aestivum "Bandera" (20 g) were placed in $100 \mathrm{~mL}$ flasks, soaked with $20 \mathrm{~mL}$ of deionized water, and autoclaved for $20 \mathrm{~min}$ at $120^{\circ} \mathrm{C}$. The treatments consisted of four Streptomyces strains, one type of fungus inoculation (F. graminearum CS3005), and two different times of antagonist inoculation.

Grains were treated with $500 \mu \mathrm{L}$ of Streptomyces strain spore suspension $\left(2 \times 10^{7}\right.$ spore/mL) and six agar-mycelium plugs ( $6 \mathrm{~mm}$ in diameter) taken from a Fusarium colony. BCAs were applied as follows: 0 DPI (Streptomyces spp. were applied at the same time as pathogen inoculation); 3 DPI (Streptomyces spp. were applied 3 days post-pathogen inoculation). The time point of 3 days post-inoculation was selected as this corresponds with the onset of toxin synthesis by the fungus [64]. Each combination of treatments was repeated four times. Three controls were included. Blank samples (grain without any treatment) inoculated only with $500 \mu \mathrm{L}$ of $10 \%$ sterile glycerol were prepared to define the background levels for each quantification, the Streptomyces-control, in which $500 \mu \mathrm{L}$ of Streptomyces spore suspension $\left(2 \times 10^{7}\right.$ spore/mL) was inoculated, and the Fusarium control, in which six agar-mycelium plugs of F. graminearum CS3005 were added to the sterilized grains. The incubation was performed at $24{ }^{\circ} \mathrm{C}$ for 11 days in the dark. Flasks were monitored and shaken daily, using a spatula when needed. Wheat grains were lyophilized (model Heto-EPD3, Thermo Scientific, San Jose, CA) for $24 \mathrm{~h}$ and ground to a fine powder. Samples were kept at $-80^{\circ} \mathrm{C}$ for subsequent extraction.

Two methods for fungal quantification were evaluated (ergosterol and qPCR). Ergosterol concentration was evaluated by chemical extraction and HPLC analysis (Sections 4.4 and 4.5). The qPCR-based Fusarium quantification was carried out based on the TRI12 gene (Sections 4.6, 4.7 , and 4.8$)$. 


\subsection{Chemicals}

Standards of ergosterol and deoxynivalenol (DON) were purchased from Sigma-Aldrich (St. Louis, MO, USA). Solvents were purchased from Sigma-Aldrich unless otherwise stated (St. Louis, MO, USA). Water was supplied by a Milli-Q apparatus (Millipore, Milford, MA, USA).

\subsection{Ergosterol Extraction and Determination}

Ergosterol extraction was performed following the procedure described in a previous research [26]. Briefly, samples were prepared as follows: $400 \mathrm{mg}$ of flour was weighed and extracted overnight using $10 \mathrm{~mL}$ of a $\mathrm{CHCl}_{3} / \mathrm{MeOH}(2: 1(v / v))$ solution. After centrifugation at $9880 \times g$ for $10 \mathrm{~min}$, the supernatant was collected, and the pellet was extracted again with $5 \mathrm{~mL}$ of the same solvent solution. The two extracts were combined, and the volume was made up to $20 \mathrm{~mL}$ using $\mathrm{CHCl}_{3} / \mathrm{MeOH}(2: 1(v / v))$. The resulting solution was diluted 1:2 prior to injection and chromatographic analysis. Ergosterol levels were used to normalize DON content per fungal mass.

The used HPLC system was an Alliance 2695 (Waters, Milford, MA, USA) equipped with a model 2998 photodiode array detector (Waters, Milford, MA, USA). A $5 \mu$ m Hypersil C18 column $\left(250 \times 4.6 \mathrm{~mm}\right.$, Thermo Scientific, San Jose, CA, USA) maintained at $30^{\circ} \mathrm{C}$ carried out the separation in isocratic mode. The flow rate was $1.0 \mathrm{~mL} / \mathrm{min}$, and the eluent was methanol. Samples were maintained at $20^{\circ} \mathrm{C}$. Chromatographic data were acquired from 195 to $350 \mathrm{~nm}$ and integrated at $282 \mathrm{~nm}$. Ergosterol stock solution $(0.26 \mathrm{mg} / \mathrm{mL})$ was prepared in $\mathrm{MeOH}$ and stored at $-20{ }^{\circ} \mathrm{C}$. Working solutions $(n=7)$ were prepared in the range of $1.3-130 \mu \mathrm{g} / \mathrm{mL}$, and $50 \mu \mathrm{L}$ was injected into the chromatographic system. Each analysis was carried out in duplicate. Ergosterol LOD was $0.2 \mu \mathrm{g} / \mathrm{mL}$ and LOQ was $1.3 \mu \mathrm{g} / \mathrm{mL}$.

\subsection{DON Extraction and Determination}

To determine the amount of DON, the flour $(1 \mathrm{~g})$ was extracted with $10 \mathrm{~mL}$ of a water/ $\mathrm{CH}_{3} \mathrm{CN}$ $(20: 80(v / v))$ solution under sonication for $30 \mathrm{~min}$. Then, the mixture was centrifuged at $1600 \times g$ for $10 \mathrm{~min}$, and the supernatant was transferred into a $10 \mathrm{~mL}$ flask where the volumes were adjusted using a water $/ \mathrm{CH}_{3} \mathrm{CN}(20: 80(v / v))$ solution. The residues were extracted again as described above, and the two extracts were analyzed separately. Mycotoxin determination was carried out using a UHPLC model Acquity (Waters, Milford, MA, USA) coupled with an HR Fourier transform Orbitrap mass spectrometer (model Exactive, Thermo Scientific, San Jose, CA, USA), equipped with a HESI-II probe for ESI and a collision cell (HCD). A Hypersil Gold $C_{18}$ column $(100 \times 2.1 \mathrm{~mm}, 1.9 \mu \mathrm{m}$, Thermo Scientific, San Jose, CA, USA) was used for the separation. The MS data were processed using Xcalibur software, version 3.0.63 (Thermo Scientific, San Jose, CA, USA). The used operative conditions and the elution gradient have been previously described [40]. DON LOD was determined at $5 \mathrm{ng} / \mathrm{mL}$ and LOQ at $50 \mathrm{ng} / \mathrm{mL}$.

\subsection{DNA Extraction}

The total DNA from flour samples was extracted using a DNA extraction kit (DNeasy mericon Food Kit, Qiagen, Hilden, Germany). Briefly, $100 \mathrm{mg}$ of the sample was weighed and processed following the manufacturer's instructions with one minor modification whereby $5 \mu \mathrm{L}$ of $20 \mathrm{mg} / \mathrm{mL}$ RNase A (Invitrogen, Thermo Fisher Scientific, Waltham, MA, USA) was added during the first incubation step at $60{ }^{\circ} \mathrm{C}$. Quantification and verification of the 260/280 ratio of the extracted DNA were carried out with a Take3 Micro-Volume plate in a microplate reader (Synergy H1, Biotek, Winooski, VT, USA). Spectrophotometric quantification was confirmed by fluorometric quantification. DNA degradation level was assessed on electrophoretic gel. DNA samples were stored in Elution buffer (EB) (Qiagen, Hilden, Germany) supplied by the DNA extraction kit at $4{ }^{\circ} \mathrm{C}$. 


\subsection{Primers and PCR Analysis}

Details of the primers used in this study are listed in Table 2. In order to obtain recA gene sequences of Streptomyces strains involved in this study, DNA was extracted as previously described [65]. Briefly, a small amount of Streptomyces spores and mycelium was transferred to a sterile microcentrifuge tube containing $27 \mu \mathrm{L}$ Tris $(10 \mathrm{mM})$-EDTA $(1 \mathrm{mM})(\mathrm{pH} 7.6)$ with a sterile toothpick; then, $3 \mu \mathrm{L} 0.4 \mathrm{M} \mathrm{KOH}-10$ $\mathrm{mM}$ EDTA was added to the tube and incubated at $70{ }^{\circ} \mathrm{C}$ for $5 \mathrm{~min}$. Next, $3 \mu \mathrm{L}$ Tris- $\mathrm{HCl}(\mathrm{pH} 4.0)$ was added to the lysate to adjust the $\mathrm{pH}$. The lysate was used directly as a DNA template for PCR amplification using primers recAPF and recAPR [66]. PCR was performed in a total volume of $25 \mu \mathrm{L}$, which contained $0.25 \mu \mathrm{L}$ of GoTaq ${ }^{\circledR}$ DNA Polymerase $5 \mathrm{U} / \mu \mathrm{L}$ (Promega, Madison, WI, USA), $5 \mu \mathrm{L}$ of Green GoTaq ${ }^{\circledR}$ Reaction Buffer 5× (Promega, Madison, WI, USA), $1 \mu \mathrm{L}$ of $10 \mathrm{mM}$ dNTP (Promega, Madison, WI, USA), $1 \mu \mathrm{L}$ of $10 \mathrm{mM}$ forward primer, $1 \mu \mathrm{L}$ of $10 \mathrm{mM}$ reverse primer, and $1 \mu \mathrm{L}$ of template DNA in nuclease-free water. The reaction conditions were initial denaturation at $95{ }^{\circ} \mathrm{C}$ for $5 \mathrm{~min}$, followed by 35 cycles of denaturation at $95^{\circ} \mathrm{C}$ for $20 \mathrm{~s}$, annealing at $60^{\circ} \mathrm{C}$ for $30 \mathrm{~s}$, and extension at $72{ }^{\circ} \mathrm{C}$ for $90 \mathrm{~s}$. A final extension was performed at $72{ }^{\circ} \mathrm{C}$ for $7 \mathrm{~min}$. Reaction products were separated by electrophoresis on a $1 \%$ agarose gel containing ethidium bromide and visualized under UV light. The PCR products were sequenced (Eurofins Genomics, Ebersberg, Germany) using the recAF primer [66]. Specific primers were designed for Streptomyces quantification based on recA gene polymorphisms. Sequences of the recA gene of DEF09, DEF20, DEF39, and DEF48 (deposited in NCBI with accession numbers MN207071-MN207074) were aligned using Geneious software (Biomatters, Auckland, New Zealand), version R11.1.4 (Figure S3). Primers for F. graminearum quantification were designed based on the TRI12 gene sequence (NC_026475). In both cases, primer specificity was tested using NCBI Primer-BLAST with default parameters against the nr database to assess the level of specificity and identify potential mistargets. Bioinformatic analysis confirmed that the specificity of the recA primers is limited to Streptomyces spp. (File S1). Similarly, a novel primer set was designed based on a specific region of TRI12 which proved species specificity to Fusarium spp. (File S2). To verify the absence of unspecific amplification of newly designed primers with other targets in wheat grains, DNA of untreated grains was amplified with recA and TRI12 primers. No signals above the LOQ were detected.

Hor1f and Hor2r primers [67], based on the plant EF1 $\alpha$ gene, were used as an internal control for each sample and to normalize fungal and bacterial DNA quantities. Streptomyces spp. and F. graminearum quantities were calculated as the target DNA/wheat DNA molecule number using the formula described in File S3 [68].

Table 2. Primers used in the study for the amplification and sequencing of the recA gene together with those used to quantify the three targets (Streptomyces spp., F. graminearum, and wheat).

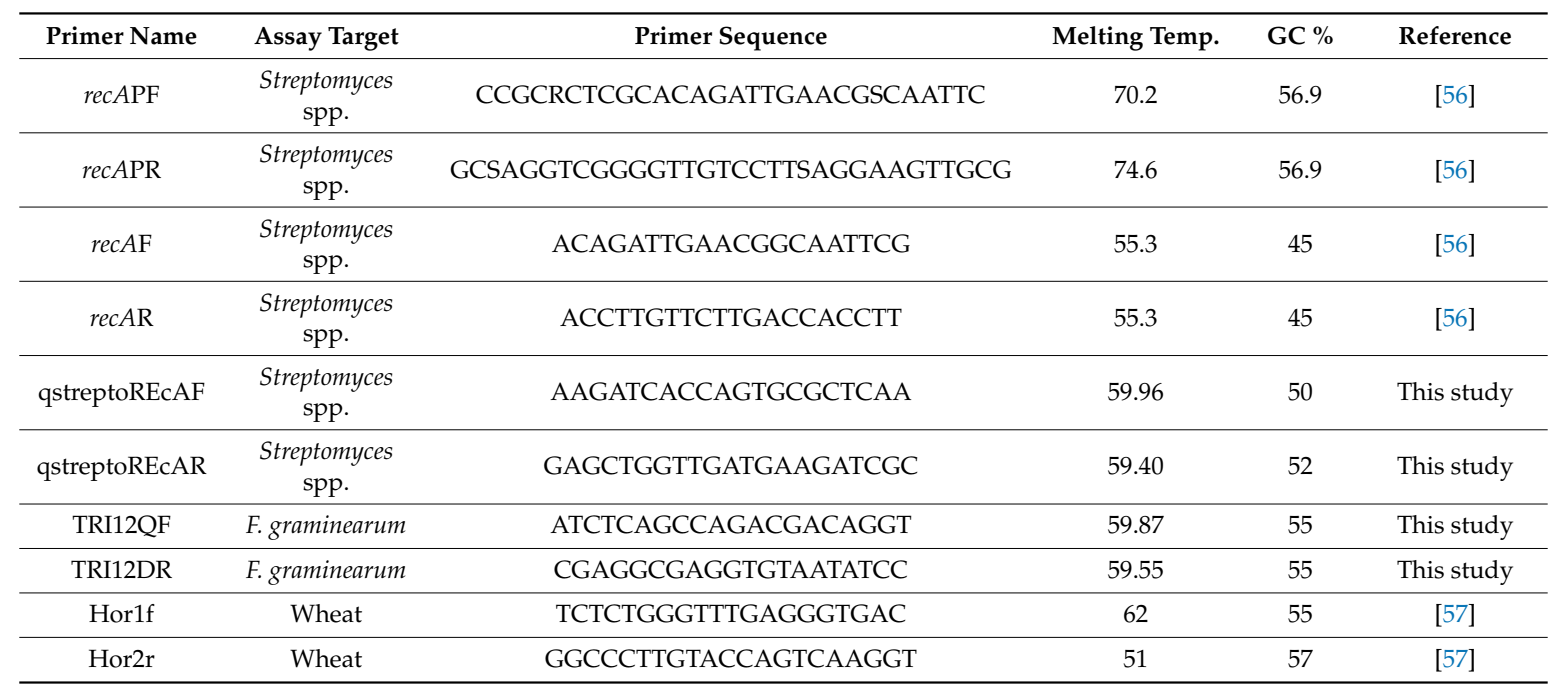




\section{8. $q P C R$ Analysis}

Quantitative real-time PCR (qPCR) was performed in order to evaluate the amount of Fusarium, Streptomyces, and wheat DNA in milled grain samples following The Minimum Information for Publication of Quantitative Real-Time PCR Experiments (MIQE) guidelines [69]. Prior to experimentation, the primers, PCR protocol specifications, and thermocycling parameters were adapted to the available reaction mixes and laboratory devices. All sample dilutions were prepared simultaneously using DEPC-treated and nuclease-free water (Fischer Scientific, Thermo Fisher Scientific, Waltham, MA, USA), and stored dilutions were kept at $4{ }^{\circ} \mathrm{C}$ during the week of the experiments. Primers were stored in aliquots at $-20^{\circ} \mathrm{C}$.

In addition, the possible interference of wheat DNA in Streptomyces and Fusarium quantification was checked by adding $5 \mathrm{ng}$ of wheat DNA extracted from untreated samples as previously described. Three replicates of each dilution $(5,0.5,0.05,0.005$, and $0.0005 \mathrm{ng})$ of the fungal and bacterial DNA were prepared and used to build the respective standard curves. Two non-template controls (NTCs) were used: water-only and background DNA-only samples. The reaction efficiency and determination coefficient $\left(R^{2}\right)$ were calculated based on the obtained $C q$ values. As there was no influence on $C q$ values due to the presence of wheat DNA (data not shown), all the experiments were carried out with standard curves that were freshly prepared with DEPC-treated and nuclease-free water (Fisher Scientific, Thermo Fisher Scientific, Waltham, MA, USA).

The qPCR reactions were carried out using an Applied Biosystems QuantStudio 3 PCR System (Thermo Fisher Scientific, Waltham, MA, USA) in standard mode. The amplification mix consisted of $2 \times$ PowerSYBR Green PCR Master Mix (Applied Biosystems, Thermo Fisher Scientific, Waltham, MA, USA), $0.3 \mu \mathrm{M}$ of each primer, and $5 \mu \mathrm{L}$ template DNA $(1 \mathrm{ng} / \mu \mathrm{L})$ in DEPC-treated and nuclease-free water (Fisher Scientific, Thermo Fisher Scientific, Waltham, MA, USA) in a total volume of $20 \mu \mathrm{L}$. The adopted amplification protocol was $2 \mathrm{~min}$ at $50^{\circ} \mathrm{C}, 10 \mathrm{~min}$ at $95^{\circ} \mathrm{C}$, followed by 40 cycles with $15 \mathrm{~s}$ at $95^{\circ} \mathrm{C}$ for denaturation and $60 \mathrm{~s}$ at $60^{\circ} \mathrm{C}$ for primer annealing, extension, and data collection. After the amplification reaction, melting curve analysis was used to determine the specificity of the amplification products by incubating them for $15 \mathrm{~s}$ at $95^{\circ} \mathrm{C}$ and $60 \mathrm{~s}$ at $60^{\circ} \mathrm{C}$ and then reading the fluorescence at $0.15^{\circ} \mathrm{C}$ increments from 60 to $95^{\circ} \mathrm{C}$. Primer specificity was verified by the presence of a single peak in the melting curve. Analysis of each DNA target (Fusarium, Streptomyces, or wheat) was conducted in 96-well optical reaction plates (Applied Biosystems, Thermo Fisher Scientific, Waltham, MA, USA) covered with Microamp optical adhesive film (Applied Biosystems, Thermo Fisher Scientific, Waltham, MA, USA), and included a standard curve for quantification that was prepared for each pair of primers with F. graminearum PH1 genomic DNA [70], Streptomyces spp. DEF09 genomic DNA, and wheat genomic DNA. The first concentration of the standard curve was $10 \mathrm{ng}$, then six dilutions 1:10 (5 ng to $0.00005 \mathrm{ng}$ ) were selected based on previous experiments. Three replicates were performed to check the linearity of the assay and efficiencies were calculated for each plate. Each sample was amplified in triplicate and NTCs were added to each plate in triplicate.

Cq values were obtained by using QuantStudio ${ }^{\mathrm{TM}}$ Design and Analysis Software version 1.5.0 (Thermo Fisher Scientific, Waltham, MA, USA) and exporting the amplification results into Excel format. The threshold for the $\mathrm{Cq}$ analysis was manually adjusted for each amplified target. Outliers among the three technical replicates were discarded if the standard error of Cq was higher than 0.2 . PCR efficiency was calculated from standard curves using the formula based on regression slopes, where the efficiency (E) of the different assays was $E=10^{-1 / \text { slope }}$. Normalization of the curves was obtained using the standard curves obtained for each plate as calibrator. All of the amplification results and calculations are available in File S3. Based on standard curves, the LOQ for recA and TRI12 assays were established to be 0.05 and $5 \mathrm{pg}$, respectively.

The amount of fungal, bacterial, and plant DNA was calculated using the adjusted Cq and the selected standard curve. After the transformation of the DNA quantity in DNA molecule numbers, the Streptomyces, Fusarium, and wheat abundance was calculated based on the size of each genome 
(see File S3), Streptomyces and Fusarium abundances were normalized with the wheat DNA abundance for each sample.

\subsection{Data Analysis}

All the statistical analyses were performed using R software, version R 3.5.3 [71], unless otherwise stated. $p<0.05$ was considered significant.

The whole study was divided into multiple experiments in order to manage the analysis. Therefore, each experimental set required separate control replicates (no-BCA treatment).

The efficacy of the bacterial antagonist treatment against fungal growth and DON production was assessed as the difference between controls and treated samples. Therefore, ergosterol quantification data, Fusarium abundance (expressed as Fusarium/wheat DNA molecule number), and DON level (expressed as $\mu \mathrm{g}$ DON/mg ergosterol) were subjected to ANOVA followed by a Tukey HSD post hoc test for multiple comparison.

In addition, the ratio between fungal quantity in control samples and treated samples was evaluated for ergosterol and qPCR data. In particular, from the qPCR data for each sample, the average of the ng of fungal DNA in control samples was divided by the ng of fungal DNA in the treated samples. Ergosterol ratios were calculated as the average of the $\mu \mathrm{g}$ of ergosterol in control treatments divided by the $\mu \mathrm{g}$ of ergosterol in the treated samples. The correlation between the ergosterol and qPCR ratios was then estimated.

In order to understand the influence of Fusarium presence on the development, the growth of Streptomyces strains at 0 DPI treatment was evaluated, comparing Streptomyces abundance in control samples (no-Fusarium spp.) and those obtained from co-cultured samples (Fusarium spp. + Streptomyces spp.). Data were subject to comparison using a t-test.

Supplementary Materials: The following are available online at http://www.mdpi.com/2072-6651/12/9/560/s1, Figure S1: Scatter plot of ratios calculated between total ng of fungal DNA in control and treated samples and ratios of ergosterol $(\mu \mathrm{g} / \mathrm{g})$ in control and treated samples, Figure S2: Fusarium graminearum growth in the flasks on wheat grains after co-inoculation (0 DPI) and late inoculation (3 DPI) with Streptomyces spp. strains DEF09, DEF20, DEF39 and DEF 48 after 11 days of incubation, Figure S3: Position of qstreptoREcAF and qstreptoREcAR on recA alignment obtained from the four Streptomyces strains involved in this study, Table S1: TRI12 (ng) and ergosterol quantification in blank samples (no-Fusarium or Streptomyces inoculation), Table S2: $p$-values of ANOVA analyses, comparing the effects of BCA treatments on fungal biomass detection by the two analysis methods (ergosterol and qPCR). In addition, results from Tukey's HSD post hoc comparison are listed as significant difference $(p<0.05)$ of the amount of ergosterol or fungal abundance in comparison with the untreated control (no-Streptomyces inoculation), File S1: Products of target templates (qstreptoREcAF/qstreptoREcAF) using NCBI Primer-BLAST (default parameters, nr database), File S2: Products on target templates (TRI12QF/TRI12DR) using NCBI Primer-BLAST (default parameters, nr database), File S3: Raw data and additional information for qPCR analysis including MIQE checklist.

Author Contributions: Conceptualization, E.M.C., A.K. and M.P.; data curation, E.M.C. and A.K.; formal analysis, E.M.C., A.K., C.G., C.P. and M.P; funding acquisition M.P., P.C., M.S. investigation, E.M.C. and C.G.; methodology, E.M.C., A.K., C.G. and M.P.; resources, P.S., M.S., P.C. and M.P.; supervision, M.P., P.C.; visualization, C.P., A.K. and M.P.; writing — original draft preparation, E.M.C., A.K. and M.P.; writing—review and editing, E.M.C., C.G., M.P., C.P., A.K., P.S., P.C. and M.S. All authors have read and agreed to the published version of the manuscript.

Funding: This research received no external funding. The article processing charge was partially covered by the University of Milan.

Acknowledgments: Elio Burrone is acknowledged for the technical support and Donald Gardiner for sharing the Fusarium graminearum CS3005 strain.

Conflicts of Interest: The authors declare no conflict of interest.

\section{References}

1. Osborne, L.E.; Stein, J.M. Epidemiology of Fusarium Head Blight on small-grain cereals. Int. J. Food Microbiol. 2007, 103-108. [CrossRef] 
2. Pasquali, M.; Beyer, M.; Logrieco, A.; Audenaert, K.; Balmas, V.; Basler, R.; Boutigny, A.L.; Chrpová, J.; Czembor, E.; Gagkaeva, T.; et al. A European database of Fusarium graminearum and F. culmorum trichothecene genotypes. Front. Mic robiol. 2016, 7, 406. [CrossRef] [PubMed]

3. Salgado, J.D.; Madden, L.V.; Paul, P.A. Quantifying the effects of Fusarium Head Blight on grain yield and test weight in soft red winter wheat. Phytopathology 2015, 105, 295-306. [CrossRef] [PubMed]

4. Beattie, S.; Schwarz, P.B.; Horsley, R.; Barr, J.; Casper, H.H. The effect of grain storage conditions on the viability of Fusarium and deoxynivalenol production in infested malting barley. J. Food Prot. 1998, 61, $103-106$. [CrossRef] [PubMed]

5. Yuan, Q.-S.; Yang, P.; Wu, A.-B.; Zuo, D.-Y.; He, W.-J.; Guo, M.-W.; Huang, T.; Li, H.-P.; Liao, Y.-C.; Yuan, Q.-S.; et al. Variation in the microbiome, trichothecenes, and aflatoxins in stored wheat grains in Wuhan, China. Toxins 2018, 10, 171. [CrossRef]

6. Lee, H.J.; Ryu, D. Worldwide occurrence of mycotoxins in cereals and cereal-derived food products: Public health perspectives of their co-occurrence. J. Agric. Food Chem. 2017, 65, 7034-7051. [CrossRef] [PubMed]

7. Maresca, M. From the gut to the brain: Journey and pathophysiological effects of the food-associated trichothecene mycotoxin deoxynivalenol. Toxins 2013, 5, 784-820. [CrossRef] [PubMed]

8. Miedaner, T.; Gwiazdowska, D.; Waśkiewicz, A. Management of Fusarium species and their mycotoxins in cereal food and feed. Front. Microbiol. 2017, 8, 1543. [CrossRef]

9. Vogelgsang, S.; Beyer, M.; Pasquali, M.; Jenny, E.; Musa, T.; Bucheli, T.D.; Wettstein, F.E.; Forrer, H.R. An eight-year survey of wheat shows distinctive effects of cropping factors on different Fusarium species and associated mycotoxins. Eur. J. Agron. 2019, 105, 62-77. [CrossRef]

10. Gilbert, J.; Haber, S. Overview of some recent research developments in Fusarium Head Blight of wheat. Can. J. Plant Pathol. 2013, 35, 149-174. [CrossRef]

11. Legrand, F.; Picot, A.; Cobo-Díaz, J.F.; Chen, W.; Le Floch, G. Challenges facing the biological control strategies for the management of Fusarium Head Blight of cereals caused by F. graminearum. Biol. Control 2017, 113, 26-38. [CrossRef]

12. Magan, N.; Aldred, D.; Mylona, K.; Lambert, R.J.W. Limiting mycotoxins in stored wheat. Food Addit. Contam. Part A 2010, 27, 644-650. [CrossRef] [PubMed]

13. Elliot, M.A.; Buttner, M.J.; Nodwell, J.R. Multicellular development in Streptomyces. In Myxobacteria: Multicellularity and Differentiation; Whitworth, D.E., Ed.; ASM Press: Washington, DC, USA, 2008; pp. $419-437$.

14. Flärdh, K.; Buttner, M.J. Streptomyces morphogenetics: Dissecting differentiation in a filamentous bacterium. Nat. Rev. Microbiol. 2009, 7, 36-49. [CrossRef] [PubMed]

15. Chater, K.F.; Biró, S.; Lee, K.J.; Palmer, T.; Schrempf, H. The complex extracellular biology of Streptomyces. FEMS Microbiol. Rev. 2010, 34, 171-198. [CrossRef] [PubMed]

16. Seipke, R.F.; Kaltenpoth, M.; Hutchings, M.I. Streptomyces as symbionts: An emerging and widespread theme? FEMS Microbiol. Rev. 2012, 36, 862-876. [CrossRef]

17. Rey, T.; Dumas, B. Plenty is no plague: Streptomyces symbiosis with crops. Trends Plant Sci. 2017, $22,30-37$. [CrossRef]

18. Nourozian, J.; Etebarian, H.R.; Khodakaramian, G. Biological control of Fusarium graminearum on wheat by antagonistic bacteria. Songklanakarin J. Sci. Technol. 2006, 28, 29-38.

19. Jung, B.; Park, S.Y.; Lee, Y.W.; Lee, J. Biological efficacy of Streptomyces sp. strain BN1 against the cereal head blight pathogen Fusarium graminearum. Plant Pathol. J. 2013, 29, 52-58. [CrossRef]

20. Winter, M.; Samuels, P.L.; Otto-Hanson, L.K.; Dill-Macky, R.; Linda, L. Biocontrol of Fusarium crown and root rot of wheat by Streptomyces isolates-it's complicated. Phytobiomes 2019, 3, 52-60. [CrossRef]

21. Palazzini, J.M.; Ramirez, M.L.; Torres, A.M.; Chulze, S.N. Potential biocontrol agents for Fusarium Head Blight and deoxynivalenol production in wheat. Crop Prot. 2007, 26, 1702-1710. [CrossRef]

22. Palazzini, J.M.; Yerkovich, N.; Alberione, E.; Chiotta, M.; Chulze, S.N. An integrated dual strategy to control Fusarium graminearum sensu stricto by the biocontrol agent Streptomyces sp. RC 87B under field conditions. Plant Gene 2017, 9, 13-18. [CrossRef]

23. Palazzini, J.; Roncallo, P.; Cantoro, R.; Chiotta, M.; Yerkovich, N.; Palacios, S.; Echenique, V.; Torres, A.; Ramirez, M.; Karlovsky, P.; et al. Biocontrol of Fusarium graminearum sensu stricto, reduction of deoxynivalenol accumulation and phytohormone induction by two selected antagonists. Toxins 2018, 10, 88. [CrossRef] [PubMed] 
24. Newitt, J.T.; Prudence, S.M.M.; Hutchings, M.I.; Worsley, S.F.; Newitt, J.T.; Prudence, S.M.M.; Hutchings, M.I.; Worsley, S.F. Biocontrol of cereal crop diseases using Streptomycetes. Pathogens 2019, 8, 78. [CrossRef] [PubMed]

25. Pellan, L.; Durand, N.; Martinez, V.; Fontana, A.; Schorr-Galindo, S.; Strub, C. Commercial biocontrol agents reveal contrasting comportments against two mycotoxigenic fungi in cereals: Fusarium graminearum and Fusarium verticillioides. Toxins 2020, 12, 152. [CrossRef] [PubMed]

26. Colombo, E.M.; Kunova, A.; Cortesi, P.; Saracchi, M.; Pasquali, M. Critical assessment of Streptomyces spp. able to control toxigenic fusaria in cereals: A literature and patent review. Int. J. Mol. Sci. 2019, $20,6119$. [CrossRef] [PubMed]

27. Essarioui, A.; LeBlanc, N.; Otto-Hanson, L.; Schlatter, D.C.; Kistler, H.C.; Kinkel, L.L. Inhibitory and nutrient use phenotypes among coexisting Fusarium and Streptomyces populations suggest local coevolutionary interactions in soil. Environ. Microbiol. 2020, 22, 976-985. [CrossRef] [PubMed]

28. Ng, H.E.; Raj, S.S.A.; Wong, S.H.; Tey, D.; Tan, H.M. Estimation of fungal growth using the ergosterol assay: A rapid tool in assessing the microbiological status of grains and feeds. Lett. Appl. Microbiol. 2008, 46, 113-118. [CrossRef] [PubMed]

29. Tangni, E.K.; Pussemier, L. Ochratoxin A and citrinin loads in stored wheat grains: Impact of grain dust and possible prediction using ergosterol measurement. Food Addit. Contam. 2006, 23, 181-189. [CrossRef] [PubMed]

30. Rao, B.S.; Rao, V.S.; Ramakrishna, Y.; Bhat, R.V. Rapid and specific method for screening ergosterol as an index of fungal contamination in cereal grains. Food Chem. 1989, 31, 51-56. [CrossRef]

31. Da Silva Bomfim, N.; Nakassugi, L.P.; Faggion Pinheiro Oliveira, J.; Kohiyama, C.Y.; Mossini, S.A.G.; Grespan, R.; Nerilo, S.B.; Mallmann, C.A.; Alves Abreu Filho, B.; Machinski, M. Antifungal activity and inhibition of fumonisin production by Rosmarinus officinalis L. essential oil in Fusarium verticillioides (Sacc.) Nirenberg. Food Chem. 2015, 166, 330-336. [CrossRef]

32. Shah, J.J.; Khedkar, V.; Coutinho, E.C.; Mohanraj, K. Design, synthesis and evaluation of benzotriazole derivatives as novel antifungal agents. Bioorg. Med. Chem. Lett. 2015, 25, 3730-3737. [CrossRef] [PubMed]

33. Zhao, Y.; Selvaraj, J.N.; Xing, F.; Zhou, L.; Wang, Y.; Song, H.; Tan, X.; Sun, L.; Sangare, L.; Minnie, Y.; et al. Antagonistic action of Bacillus subtilis strain SG6 on Fusarium graminearum. PLoS ONE 2014, 9, e92486. [CrossRef] [PubMed]

34. Bluhm, B.H.; Woloshuk, C.P. Amylopectin induces fumonisin B1 production by Fusarium verticillioides during colonization of maize kernels. Mol. Plant-Microbe Interact. 2005, 18, 1333-1339. [CrossRef] [PubMed]

35. Tellenbach, C.; Grünig, C.R.; Sieber, T.N. Suitability of quantitative real-time PCR to estimate the biomass of fungal root endophytes. Appl. Environ. Microbiol. 2010, 76, 5764-5772. [CrossRef]

36. Zhang, Y.J.; Fan, P.S.; Zhang, X.; Chen, C.J.; Zhou, M.G. Quantification of Fusarium graminearum in harvested grain by real-time polymerase chain reaction to assess efficacies of fungicides on Fusarium Head Blight, deoxynivalenol contamination, and yield of winter wheat. Phytopathology 2009, 99, 95-100. [CrossRef]

37. Bilska, K.; Kulik, T.; Ostrowska-Kołodziejczak, A.; Buśko, M.; Pasquali, M.; Beyer, M.; Baturo-Cieśniewska, A.; Juda, M.; Załuski, D.; Treder, K.; et al. Development of a highly sensitive FcMito qPCR assay for the quantification of the toxigenic fungal plant pathogen Fusarium culmorum. Toxins 2018, 10, 211. [CrossRef]

38. Gimeno, A.; Sohlberg, E.; Pakula, T.; Limnell, J.; Keller, B.; Laitila, A.; Vogelgsang, S. TaqMan qPCR for quantification of Clonostachys rosea used as a biological control agent against Fusarium graminearum. Front. Microbiol. 2019, 10, 1627. [CrossRef]

39. Sanzani, S.M.; Li Destri Nicosia, M.G.; Faedda, R.; Cacciola, S.O.; Schena, L. Use of quantitative PCR detection methods to study biocontrol agents and phytopathogenic fungi and oomycetes in environmental samples. J. Phytopathol. 2014, 162, 1-13. [CrossRef]

40. Colombo, E.M.; Pizzatti, C.; Kunova, A.; Gardana, C.; Saracchi, M.; Cortesi, P.; Pasquali, M. Evaluation of in-vitro methods to select effective Streptomycetes against toxigenic Fusaria. PeerJ 2019, 7, e6905. [CrossRef]

41. Colombo, E.M.; Pizzatti, C.; Kunova, A.; Saracchi, M.; Cortesi, P.; Pasquali, M.; Pizzatti, C.; Saracchi, M.; Cortesi, P.; Pasquali, M. Selection of an endophytic Streptomyces sp. strain DEF09 from wheat roots as a biocontrol agent against Fusarium graminearum. Front. Microbiol. 2019, 10, 2356. [CrossRef]

42. Seong, K.Y.; Pasquali, M.; Zhou, X.; Song, J.; Hilburn, K.; McCormick, S.; Dong, Y.; Xu, J.R.; Kistler, H.C. Global gene regulation by Fusarium transcription factors Tri6 and Tri10 reveals adaptations for toxin biosynthesis. Mol. Microbiol. 2009, 72, 354-367. [CrossRef] [PubMed] 
43. Zucchi, T.D.; De Moraes, L.A.B.; De Melo, I.S. Streptomyces sp. ASBV-1 reduces aflatoxin accumulation by Aspergillus parasiticus in peanut grains. J. Appl. Microbiol. 2008, 105, 2153-2160. [CrossRef]

44. Bonaldi, M.; Kunova, A.; Saracchi, M.; Sardi, P.; Cortesi, P. Streptomycetes as biological control agents against basal drop. Acta Horticulturae 2014, 1044, 313-318. [CrossRef]

45. Mille-Lindblom, C.; Fischer, H.J.; Tranvik, L. Antagonism between bacteria and fungi: Substrate competition and a possible tradeoff between fungal growth and tolerance towards bacteria. Oikos 2006, 113, 233-242. [CrossRef]

46. Jones, S.E.; Ho, L.; Rees, C.A.; Hill, J.E.; Nodwell, J.R.; Elliot, M.A. Streptomyces exploration is triggered by fungal interactions and volatile signals. Elife 2017, 6, e21738. [CrossRef]

47. Fguira, L.F.B.; Smaoui, S.; Karray-Rebai, I.; Bejar, S.; Mellouli, L. The antifungal activity of the terrestrial Streptomyces US80 strain is induced by heat-killed fungi. Biotechnol. J. 2008, 3, 1058-1066. [CrossRef]

48. Elleuch, L.; Smaoui, S.; Najah, S.; Chakchouk, A.; Sellem, I.; Karray-Rebai, I.; Mellouli, L. Production of diketopiperazine derivative cyclo (L-Leu-L-Arg) by Streptomyces sp. TN262 after exposure to heat-killed fungus Fusarium sp. J. Chem. Soc. Pakistan 2013, 35, 1530-1534.

49. Zhao, J.; Xue, Q.H.; Niu, G.G.; Xue, L.; Shen, G.H.; Du, J.Z. Extracellular enzyme production and fungal mycelia degradation of antagonistic Streptomyces induced by fungal mycelia preparation of cucurbit plant pathogens. Ann. Microbiol. 2013, 63, 809-812. [CrossRef]

50. Pasquali, M.; Migheli, Q. Genetic approaches to chemotype determination in type B-trichothecene producing Fusaria. Int. J. Food Microbiol. 2014, 189, 164-182. [CrossRef]

51. Martinez Tuppia, C.; Atanasova-Penichon, V.; Chéreau, S.; Ferrer, N.; Marchegay, G.; Savoie, J.-M.; Richard-Forget, F. Yeast and bacteria from ensiled high moisture maize grains as potential mitigation agents of fumonisin B 1. J. Sci. Food Agric. 2017, 97, 2443-2452. [CrossRef]

52. He, J.; Boland, G.J.; Zhou, T. Concurrent selection for microbial suppression of Fusarium graminearum, Fusarium Head Blight and deoxynivalenol in wheat. J. Appl. Microbiol. 2009, 106, 1805-1817. [CrossRef] [PubMed]

53. Dalié, D.; Pinson-Gadais, L.; Atanasova-Penichon, V.; Marchegay, G.; Barreau, C.; Deschamps, A.; Richard-Forget, F. Impact of Pediococcus pentosaceus strain L006 and its metabolites on fumonisin biosynthesis by Fusarium verticillioides. Food Control 2012, 23, 405-411. [CrossRef]

54. Palaniyandi, S.A.; Yang, S.H.; Zhang, L.; Suh, J.W. Effects of Actinobacteria on plant disease suppression and growth promotion. Appl. Microbiol. Biotechnol. 2013, 97, 9621-9636. [CrossRef] [PubMed]

55. Sakuda, S.; Ono, M.; Ikeda, H. Blasticidin A as an inhibitor of aflatoxin production by Aspergillus parasiticus of aflatoxin. J. Antibiot. 2000, 53, 1265-1271. [CrossRef]

56. Kondo, T.; Sakurada, M.; Okamoto, S.; Ono, M.; Tsukigi, H.; Suzuki, A.; Nagasawa, H.; Sakuda, S. Effects of aflastatin A, an inhibitor of aflatoxin production, on aflatoxin biosynthetic pathway and glucose metabolism in Aspergillus parasiticus. J. Antibiot. 2001, 54, 650-657. [CrossRef]

57. Yoshinari, T.; Noda, Y.; Yoda, K.; Sezaki, H.; Nagasawa, H.; Sakuda, S. Inhibitory activity of blasticidin A, a strong aflatoxin production inhibitor, on protein synthesis of yeast: Selective inhibition of aflatoxin production by protein synthesis inhibitors. J. Antibiot. 2010, 63, 309-314. [CrossRef]

58. Bhatia, S.K.; Bhatia, R.K.; Choi, Y.K.; Kan, E.; Kim, Y.G.; Yang, Y.H. Biotechnological potential of microbial consortia and future perspectives. Crit. Rev. Biotechnol. 2018, 38, 1209-1229. [CrossRef]

59. Abbasi, S.; Safaie, N.; Sadeghi, A.; Shamsbakhsh, M. Tissue-specific synergistic bio-priming of pepper by two Streptomyces species against Phytophthora capsici. PLoS ONE 2020, 15, e0230531. [CrossRef]

60. Pasquali, M.; Cocco, E.; Leclercq, C.C.; Planchon, S.; Guignard, C.; Renaut, J.; Hoffmann, L. A Fusarium graminearum strain-comparative proteomic approach identifies regulatory changes triggered by agmatine. J. Proteomics 2016, 137, 107-116. [CrossRef]

61. Pani, G.; Dessì, A.; Dallocchio, R.; Scherm, B.; Azara, E.; Delogu, G.; Migheli, Q.M. Natural phenolic inhibitors of trichothecene biosynthesis by the wheat fungal pathogen Fusarium culmorum: A computational insight into the structure-activity relationship. PLOS ONE 2016, 11. [CrossRef]

62. Sardi, P.; Saracchi, M.; Quaroni, S.; Petrolini, B.; Borgonovi, G.E.; Merli, S. Isolation of endophytic Streptomyces strains from surface-sterilized roots. Appl. Environ. Microbiol. 1992, 58, 2691-2693. [CrossRef] [PubMed]

63. Gardiner, D.M.; Stiller, J.; Kazan, K. Genome sequence of Fusarium graminearum isolate CS3005. Genome Announc. 2014, 2, e00227-14. [CrossRef] [PubMed] 
64. Ponts, N.; Pinson-Gadais, L.; Verdal-Bonnin, M.N.; Barreau, C.; Richard-Forget, F. Accumulation of deoxynivalenol and its 15 -acetylated form is significantly modulated by oxidative stress in liquid cultures of Fusarium graminearum. FEMS Microbiol. Lett. 2006, 258, 102-107. [CrossRef] [PubMed]

65. Sun, Z.; Huang, Y.; Wang, Y.; Zhao, Y.; Cui, Z. Potassium hydroxide-ethylene diamine tetraacetic acid method for the rapid preparation of small-scale PCR template DNA from Actinobacteria. Mol. Genet. Microbiol. Virol. 2014, 29, 42-46. [CrossRef]

66. Guo, Y.P.; Zheng, W.; Rong, X.Y.; Huang, Y. A multilocus phylogeny of the Streptomyces griseus 16S rRNA gene clade: Use of multilocus sequence analysis for Streptomycete systematics. Int. J. Syst. Evol. Microbiol. 2008, 58, 149-159. [CrossRef]

67. Nicolaisen, M.; Suproniene, S.; Nielsen, L.K.; Lazzaro, I.; Spliid, N.H.; Justesen, A.F. Real-time PCR for quantification of eleven individual Fusarium species in cereals. J. Microbiol. Methods 2009, 76, 234-240. [CrossRef]

68. Pasquali, M.; Piatti, P.; Gullino, M.L.; Garibaldi, A. Development of a real-time polymerase chain reaction for the detection of Fusarium oxysporum f. sp. basilici from basil seed and roots. J. Phytopathol. 2006, 154, 632-636. [CrossRef]

69. Bustin, S.A.; Benes, V.; Garson, J.A.; Hellemans, J.; Huggett, J.; Kubista, M.; Mueller, R.; Nolan, T.; Pfaffl, M.W.; Shipley, G.L.; et al. The MIQE guidelines: Minimum information for publication of quantitative real-time PCR experiments. Clin. Chem. 2009, 55, 611-622. [CrossRef]

70. Cuomo, C.A.; Güldener, U.; Xu, J.-R.; Trail, F.; Turgeon, B.G.; Di Pietro, A.; Walton, J.D.; Ma, L.-J.; Baker, S.E.; Rep, M.; et al. The Fusarium graminearum genome reveals a link between localized polymorphism and pathogen specialization. Science 2007, 317, 1400-1402. [CrossRef]

71. R Core Team. R: A Language and Environment for Statistical Computing, version R 3.5.3; R Core Team: Copenhagen, Denmark, 2019.

(C) 2020 by the authors. Licensee MDPI, Basel, Switzerland. This article is an open access article distributed under the terms and conditions of the Creative Commons Attribution (CC BY) license (http://creativecommons.org/licenses/by/4.0/). 